\title{
Utazás az akadálymentesség, a fogyatékosság és a fenntarthatóság multidiszciplináris és bölcseleti dimenzióiba
}

\author{
Szerzők: Farkas Jácint ${ }^{1}$ - Petykó Csilla²
}

A fenntarthatóság elvei egyre inkább teret nyernek a turizmus tudományának gondolatkörében és gyakorlatában. Ennek egyik dimenziója az akadálymentesités, amit az EU által megfogalmazott keretrendszerekben és a hozzájuk kapcsolódó konkrét ajánlásokban is megtalálunk.

Ha akadálymentesitésrôl beszélünk azt tapasztaljuk, hogy a fogalmat a többség a közösségi élettérben létrejövő helyváltoztatás fizikai korlátainak felszámolásaként értelmezi. Véleményünk szerint azonban az akadálymentesség gondolatkörében nem kizárólagosan annak fizikai megvalósulása jelenti az egyetlen hasznositható értelmezési keretet. Mint látni fogjuk, az életfilozófia olvasatában az ember alapvetố tulajdonságai között tartjuk számon az akadálymentesitó és az egzisztenciálisan fogyatékos mivoltot is. Tehát sem az akadálymentesség, sem a fogyatékosság meghatározásunk nem eredeztethetố - kizárólag - a jelenkori kulturális és társadalmi kiteljesedésünkböl, sokkal inkább az emberségünket adó alaptulajdonságok közé kell sorolnunk mindkettôt.

Jelen tanulmányunk célja rávilágítani arra, hogy az akadálymentesítés fogalomköre messze túlmutat a fizikai élettér elérhetôvé tételén, ahogyan a fenntarthatóság keretei is jelentôsen átértelmezödnek, kitágulnak az életfilozófiai megközelitéseknek a turizmus tudományterületére történó beemelésével.

Kulcsszavak: fenntarthatóság, életfilozófia, egzisztenciális fogyatékosság, akadálymentesség, felelősségvállalás, kommunikáció.

\section{Bevezetô}

Az utazás metaforája a filozófia világának egyik legkedveltebb hasonlata volt, akár az ókori görög, akár a keleti filozófusok munkásságát állítjuk vizsgálódásunk ${ }^{3}$ középpontjába. Ez a gondolati ív nem szakadt meg jelen korunkra sem, s mint látni fogjuk, az egzisztenciálfilozófusok is előszeretettel használják az utazás legkülönbözőbb hasonlatait bölcseletük valódiságának alátámasztása érdekében. Egyrészről tehát az irántuk tanúsított tisztelet, másrészről a célként kitúzött fogalmikeret-bővítés jobb érthetősége érdekében szinonimaként fogjuk használni az utazás tudománya kifejezést a már megszokott turizmustudomány szóösszetétellel.

$\mathrm{Az}$ életfilozófiai megközelítés NyugatEurópában mára már nem ismert, Észak-

\footnotetext{
${ }^{1}$ doktorjelölt, Budapesti Corvinus Egyetem, farkas.jacint@gmail.com ${ }^{2}$ egyetemi docens, Budapesti Gazdasági Egyetem, petyko.csilla@uni-bge.hu ${ }^{3} \mathrm{Az}$ általunk a későbbiekben többször is használt vizsgálódás kifejezés a filozófiai, bölcseleti kutatásmódszertan originális elnevezése. A fogalmi jelentésvilágok továbbgondolására, kifejtésére és kiterjesztésére kívánja felhívni a figyelmet.
}

Amerikában pedig soha nem gyakorolt igazán nagy hatást. Karl Jaspers vagy Martin Heidegger neve sokak számára mégis ismerősen csenghet, mindkettőjük életmúve meghatározó a filozófia XX. századi történetében. Az ő munkásságuk nyomán kijelenthető, hogy a bölcsesség szeretetének nagyon is gyakorlati, ha tetszik, hétköznapi olvasata is a rendelkezésünkre áll.

Jogosan vetődhet fel a kérdés, hogy az utazás, turizmus tudományának szüksége van-e egy újabb megközelítési módra, különös tekintettel annak életfilozófiai jellegére. Úgy gondoljuk, a válasz egyértelmúen igen, hiszen az akadálymentesítés és a fenntarthatóság fogalmi kereteinek kiemelése a fizikai térből, az említett bölcseleti háttér ismerete nélkül nem, vagy csak sokkal nehezebben jöhetett volna létre.

Tanulmányunk két meghatározó tengely mentén vizsgálja az utazói magatartás, az akadálymentesítés, a fogyatékosság és nem utolsó sorban a fenntarthatóság kérdésköreit. Az életfilozófiai tartalmak kutatásmódszertana a filozófiai vizsgálódások hermeneutikai irányát követi, mely a nyugati kultúrkörben elsősorban Martin Heidegger és Hans-Georg Gadamer nevéhez fúződik. A félreértések elkerülése végett megjegyezzük, hogy ez az értelmezési módszer közel sem a leírt szövegek 
Lektorált tanulmányok

életre keltéséről szól csupán, hanem az emberi tevékenység szinte valamennyi volumenére kiterjeszthető. Ezt a kutatási formát kiegészítettük még a Karl Jaspers és Nágárdzsuna ${ }^{4}$ nevéhez fúződô életfilozófiai gyakorlatorientált létértelmezési módszerek alkalmazásával. Vizsgálódásunk második tengelyét a turizmus területén végzett elemzések adták, melyek révén betekintést nyertünk a fenntarthatóság és az akadálymentesség fogalmának értelmezésébe az utazás tudománya mentén.

\section{Filozófiai antropológiai szempontú megközelítêsek}

Örvendetes módon az akadálymentesítés, mint környezetátalakító tevékenység, egyre ismertebb és elfogadottabb nemcsak Európában, hanem a világ szinte valamennyi területén. Sajnos azonban egyelöre fóként a fogyatékosság kísérójelenségét értjük a fogalom alatt (KÖNCZEI-HERNÁDI 2015).

Mi, akik az utazás világának feltérképezésében közösen gondolkodunk és tevékenykedünk, egyre inkább ráeszmélünk, hogy ennél sokkal többről van szó. GEHLEN (1976) megfogalmazása szerint az ember hiánylény, s ennek következtében mintegy rákényszerültt, hogy létrehozza az emberi kultúrát. Mint ebból látszik, a filozófiai antropológia fontos kérdésnek tekinti az ember sajátos helyzetét, a többi élólényhez képest önmagában sebezhető mivoltát. ADLER (1998) külön fejezetet szentel Életismeret címú könyvében a fogyatékossággal éló emberek elfogadásával kapcsolatos nehézségeknek, de sorai közül kiolvasható, hogy egyfajta lehetőségként is tekint a fizikai, mentális, érzékszervi stb. sérüléssel éló emberekre. Lehetóségként arra, hogy jobban megismerjük saját korlátainkat, és képesek legyünk azokat minél inkább kitágítani.

Érdekes lehet KROPOTKIN (1924) gondolatvilágának rövid felidézése, ugyanis az orosz geográfus és filozófus szibériai utazásai és hosszú ott tartózkodása során empirikus bizonyítékok százain keresztül igazolta állításai valóságtartalmát, miszerint az evolúció nem elsősorban a fajok közötti versengésen, harcon keresztül teljesedik ki, hanem az általa kölcsönös segítségnek nevezett gyakorlaton át. POLÁNYI (2004) reciprocitás elmélete is arra késztet bennünket, hogy úgy tekintsünk az emberre is, mint segítségre és együttmúködésre szorított létformára.

Az utazás az ember egyik legősibb tevékenysége. Óseink még gyakran kényszerből járták be a körülöttük lévő területeket, amikor is nem elsôsorban a megismerés, hanem a túlélés kényszere

\footnotetext{
Nágárdzsuna II. századi indiai buddhista filozófus, a Nálanda-i egyetem egykori apátja, az ürességfilozófia iskola alapítója. Hazájában a második Buddhaként is tisztelik.
}

hajtotta őket. Sok ezer év kényszerú utazói létének tanulságai beépültek az emberiség kultúrájába, mintegy generálták és generálják a korunkban kicsúcsosodó technikai civilizációt. Adler és Kropotkin úgy értelmezte a fent részletezett együttmúködési szükségleteket, hogy azok nélkülözhetetlen komponensei nemcsak a létfenntartásnak, hanem magának az emberré válásnak is. Manapság az utazás javarészben az élményszerzés és a boldogságkeresés egyik eszköze (MICHALKÓ 2010). Ezt lehetne akár úgy is értelmezni, hogy a fentiekben taglalt szükségszerú utazás és együttmúködési alapmotívum mára már csak marginális szerepet játszik a világot bejáró ember százmilliók motivációs palettáján.

Azt állítjuk, hogy a ma létrejövő utazások indikátoraiban legalább olyan súllyal van jelen az emberben rejló együttmúködési hajlandóság és szükségszerúség, továbbá a felfedezés és a kommunikáció vágya, mint ôseinknél. Természetesen ezek kiegészülttek a már említett élményszerzés és boldogságkeresés dimenzióival, és ezek értelmezhetők egy életfilozófiai megközelítésből eredő, létbéli útkeresés mindannyiunkban meglévő, ha nem is minden esetben tudatosuló, vágyával (JASPERS 2008).

Mint látható, az akadálymentesító ember (FARKAS 2019) fogalma olyan természetes emberi tulajdonságot és adottságot hordoz és jelöl, mely nem a már említett klasszikus akadálymentesító tevékenység csupán, hanem az ember alapvetô tulajdonsága.

Az ember tehát akadálymentesító tevékenységének is köszönheti jelenlegi technikai és kulturális eredményeit, s mindezeket az együttmúködési képessége nélkül nem érhette volna el. Véleményünk szerint az akadálymentesítés és a fenntarthatóság értelmezésdimenzióinak kiterjesztése akár a turizmus fenntarthatóságának és ésszerúsítésének elkerülhetetlen továbbgondolása vonatkozásában is kiemelt szerepet kell kapjon.

A fentiek ismeretében - a teljesség igénye nélkül - nézzük meg részletesebben, hogyan kapcsolódnak egymáshoz az életfilozófiai vizsgálódások és az utazás tudományának bizonyos aspektusai.

Örök kérdés - földrajzi elhelyezkedésünktól és kulturális beágyazódásunktól függetlenül - miért is vagyunk itt a Földön, illetve miképpen tölthetjük ki a rendelkezésünkre álló életidônket? A vallások, filozófiai iskolák, majd késôbb a szaktudományok és szakfilozófiák kart karba öltve igyekeznek válaszokat találni a feltett kérdésekre. Az általunk preferált egzisztenciálfilozófiai bölcseleti irányzat is kísérletet tesz erre, de ahogy BERGSON (1987) megfogalmazza, a filozófus feladata abban áll, hogy valódi kérdéseket fogalmazzon meg a létezés- 
re vonatkozóan, és a létezés konkrét összetevőibe belemerülve, azokból kiindulva alkosson fogalmakat és elméleteket, melyek soha nem lehetnek véglegesek és merevek.

Hermeneutikai kutatásmódszertanunk kitúnően illeszthetô ehhez a fogalom- és elméletalkotási módhoz, melynek sarkalatos pontja esetünkben a vizsgált emberi utazói tevékenység feltérképezése. Ez a GADAMER-i ${ }^{5}$ (2003) vizsgálódás alapvetését is szem előtt tartja, miszerint az adott vizsgálódás alá vont léttevékenység egy konkrét társadalmi és szociokulturális kontextus eredménye, vagyis nincsenek merev, örök szubsztanciális igazságok a világunkban. Tehát az utazás és annak fenntarthatósága egy újrafelfedezési, soha meg nem szúnő emberi folyamat, ami saját korunk társadalmi, kommunikációs és gazdasági életszövetébe illeszkedő módon vizsgálandó.

Az 1920-as évek elején, közepén egyre markánsabban fogalmazódott meg az az álláspont, miszerint az ember és a kultúrája eljutott abba a technikai fejlettségi állapotba, hogy az eredendően természeti státusza a kulturális centrumává alakult át, ami annyit jelent, hogy immár felette áll a természetnek, nem függ tőle, sőt mi több, annak alakítójává is vált. Úgy gondoljuk, ez a kissé materialistának ható megállapítás - akár csak a tagadhatatlan klímakatasztrófa árnyékában többszörösen megdőlt, és egyetértünk Jaspers azon gondolatával, miszerint az ember szimbiotikus viszonya az anyabolygóval, és tágabb értelemben az annak otthont adó univerzummal, megkérdőjelezhetetlen (JASPERS 1996).

Ezen állítás majdnem tökéletesen megegyezik a buddhista filozófia alapvetô tanításaival, melyek egészen a Buddha tanításaiig, és az Európában egyre inkább ismertté váló - a bevezetőben már említett II. századi indiai filozófus - Nágárdzsuna gondolatvilágáig is visszavezethetőek.

A gondolkodó ember tehát legalább annyira függött a történetiség kezdetétől fogva az őt körülölelő és fenntartó természettől, mint a túlélését biztosító kiemelkedő kognitív képességeitől, a testi és a tudati adottságaiból adódó együttmúködési és együttélési létmódjától. A felnôtt - nevezzük ez esetben emberspecifikus - viselkedés fokmérője lehet például ennek a kölcsönös és feloldhatatlan

\footnotetext{
${ }^{5}$ Az európai kultúrkörben a filozófiai hermeneutika atyjaként Hans-Georg Gadamert tarják számon - ami csak részben felel meg a valóságnak azonban Gadamer munkássága Heidegger filozófiájának tükrében fedi fel valós formáját. Az Igazság és módszer címü korszakalkotó műve forradalmi megállapításokat tartalmaz a leírt szövegek értelmezésének és tulajdonképpeni életre keltésének tekintetében. Például a történelmi szemléletet, történeti szemléletre cseréli, ezzel is jelezve, hogy ha a múl egy adott pillanatnyiságában, arra a konkrét élet- és társadalmi helyzetre reflektáló, írásba foglalt gondolatok a jelen szituációiban újra testesülvén, új értelmet is nyernek (GADAMER 2003).
}

egymásrautaltságnak a felismerése, valamint a fenntarthatósági feltételeinek kialakítása, ápolása és gondozása.

Az ember mindezekhez szervesen illeszkedő módon utazó lény is, mely tevékenysége során a homo sapiens kifejezés egy kevéssé ismert kontextusa értelmében valóban belekóstoló lénye is a létezésnek.

Kis merészséggel tovább szőve a vizsgálódás filozófiai szövetét, azt is kijelenthetjük, hogy a gondolkodó, belekóstoló és utazó tulajdonságokkal élő ember legalább ennyire akadálymentesító létező is. Emlékezzünk arra, hogy a tanulmány elején az utazást, az utazói létformát úgy is említettük, mint kényszerpályát őseink számára. Ez önmagában is igazolja, hogy az ember folyamatosan szembesült az életben maradása során elébe kerülő akadályokkal. Bizonyos esetekben akadállyá válhatott egy adott földrajzi terület növény- és vadállományának meggyérülése. Tehát a helyváltoztatási kényszer egyfajta akadálymentesítési, fajfenntartási módnak is tekinthető, mint ahogy a késóbbiekben megalkotott - egyik legfontosabb találmány, a kerék is besorolható a fenti kategóriába.

Így az akadálymentesító ember szembesült saját korlátaival, ha úgy tetszik, fogyatékosságaival. GEHLEN (1976) ezt úgy értelmezte, hogy a kultúra kialakulása innen is ered, vagyis az ember állatokhoz képest gyenge fizikális és biológiai fegyvermentessége mintegy természetes módon hozta létre az együttmúködés alaprajzát, melyból napjainkig is épül (ha nem is annyira szépül) az emberi kultúra.

Mindezek értelmében, az akadálymentesítő tevékenység és a fenntartható élettér kialakítása és folyamatos adaptálása az állandóan változó körülményekhez, egyáltalán nem a modern technikai varázslat világában élő ember találmánya.

Ennyi kitekintés után nyissunk egy új utat vizsgálódásunkban, és járjuk körbe - amennyire a szúkös keretek engedik - a jelenkor utazási kényszerében rejlő lehetőségeket, melyek reményeink szerint új megvilágításba helyezik az utazás, a fogyatékosság, a fenntarthatóság és az akadálymentesítés talán nem is annyira jól ismert fogalmait.

\section{Az egzisztenciális fogyatékosság, mint az ember egyik alaptulajdonsága}

Mint a következő fejezetben részletesen kifejtjük az életfilozófia és az utazás tudományának kontextualizálása által -, az ember jó esetben ismereteket és élményeket szerez az utazásai alkalmával. De vajon szembesül-e a saját egzisztenciális fogyatékosságával (FARKAS 2019) és akadálymentesítő lényének ilyen aspektusaival? 
Lektorált tanulmányok

Ehhez elsóként szükségesnek látjuk kifejteni, mit is jelent az egzisztenciális fogyatékosság fogalma, illetve miért fontos ezt az utazás kontextusába belehelyezni.

Napjaink hazai és nemzetközi turisztikai és gazdasági tevékenységének tervezése és szabályozása kapcsán a fogyatékossággal éló utazók és segítóik akadálymentes életfeltételeinek biztosítása prioritást élvez. Gondoljunk csak arra, hogy például a 2014-es és a 2016-os évet az UNWTO a segítséggel élóknek szentelte (MICHALKÓ 2016) ${ }^{6}$. Azonban, mint már utaltunk rá, és bízunk benne, hogy sorainkból is kiolvashatóvá válik, a fogyatékosság és az akadálymentesítés esetében alapvetően mást és máshogy gondolunk, mint ami például a fogyatékosságtudomány igen innovatív fogalomkészletéből következik.

Joggal értelmezi úgy KÁLMÁN és KÖNCZEI (2002) a modern társadalmak fogyatékosság definícióit, mintha azok egyfajta szocialitásbeli hiátusok volnának, melyek elsósorban abból adódnak, hogy a társadalmi berendezkedések technikailag és jogilag még nem elég fejlettek ahhoz, hogy a funkcionális és tartós fogyatékossággal élő emberek - akik a világ lakosságának mintegy 5-6\%-át teszik ki - számára kellóen kidolgozott és megvalósított akadálymentes, egyenló esélyú környezetet hozzanak létre.

A fogyatékosság általunk röviden bemutatásra kerüló, kiterjesztett és több új dimenzióba is belehelyezett modellje értelmében az ember - ha ezt sokszor le is tagadja - kénytelen szembesülni a fogyatékosságaival (testi, érzékszervi, mentális vagy halmozott, tehát funkcionális), melyek a többségében nyilvánvaló akadályozottságon messze túlmutatnak, viszont a létezés szereplójeként egyetlen embertársunk sem mentesülhet hatásaik alól.

Egzisztenciális fogyatékosságunk ${ }^{7}$ három fogalomés tulajdonságcsoport rövid felvázolása által válik nyilvánvalóvá:

- Az ember tisztában van földi létének végességével, éppen ezért keres állandónak túnó kapaszkodókat egy folyton változó és átalakuló világban. Az állandó változást vagy nem ismeri fel, vagy azt önmaga előtt is letagadja, ezzel sok egyéb mellett jelentôs akadálygenerálást hajt végre.

\footnotetext{
A 2014-es év jelmondata: „Community building”, 2016-os évé pedig: „Tourism for All”, rámutatva ezekkel is az érintett emberek hozzáférés szükségleteire és azok megvalósíthatóságára egyaránt.

A tanulmány kereteit szétfeszítené az egzisztenciális fogyatékosság filozófiai hátterének bővebb kifejtése, erre további értekezések lesznek majd hivatottak. Bízunk abban, hogy az eddigi gondolatmenet és az ezt követő fejtegetések összességében körvonalazni fogják, miért is tartjuk szükségesnek és igazolhatónak a funkcionális és az egzisztenciális fogyatékosság megkülönböztetését.
}

- Majdnem ugyanez a helyzet a létezés ki nem elégítő voltának fel nem ismerésével. Ezt a buddhista filozófia a dukkha ${ }^{8}$ fogalmának segítségével mutatja be, melynek lényege, hogy a kelló éberség hiánya és a tudatlanság fennállása okán az ember folyamatosan ragaszkodik olyan állandó, megfogható és biztos pontokhoz az életben, melyek által csökkenthetônek véli a belsó feszültségeit. Márpedig ilyenek Buddha tanításának értelmében nem léteznek.

- A Heidegger által bevezetett létfelejtés és annak az elfelejtése (HEIDEGGER 2019), egy újabb láncszemmel bővül, melyet az emberségfelejtés elnevezéssel illetünk (FARKAS 2019).

Tehát ezek a nagyon is emberi tulajdonsághalmazok nem - a fogyatékosság tudománya által is definiált - testi, mentális, vagy szenzuális képességeink, etc. és adottságaink másságának szempontjaira helyezik a hangsúlyt, hanem a mindannyiunkban potenciálisan meglévó fentebb részletezett alaptulajdonságokra. Mint ahogy a már említett akadálymentesítési adottságaink és a kényszerúen kialakult ilyen képességeink sem a funkcionális fogyatékosság ma (köz)ismert doktrínáira kínáltak és kínálnak elsődlegesen megoldást, úgy az egzisztenciális fogyatékosság tudatot feszítô mivoltára sem adnak gyógyírt.

\section{Az életbölcselet és az utazás tudományának közös értelmezési dimenziói}

Az utazás boldogít, mondja MICHALKÓ (2010). Az utazás boldogithat, mondjuk mi. Heidegger úgy definiálja a Lét és idő címú fômúvében az emberi létezés mivoltát, hogy az ismeretlenségből az ismeretlenségbe tartó lény mintegy belezuhan a létezésbe, és felismerve ezt a sodródást, létrehozza a nyelvet, mint a lét házát (HEIDEGGER 2019). Ez a folyamat rémisztőnek túnik, már csak azért is, mert ekként is van megfogalmazva. Hogyan tudjuk ezt a koordinálatlan zuhanást és sodródást valóban minőségi utazássá transzformálni, és így valóban boldogítóvá tenni az ember hajózását élet és halál között? A lét háza Heidegger szerint a nyelv. Segít nekünk relatív biztonságot teremteni a folyamatos változások létóceánján.

A lét háza kifejezés jelentése a nyelven túl kiterjeszthetô arra a szúkebb környezetre is,

\footnotetext{
${ }^{8}$ Az olvasó erröl a kultúrkörünkben többségében rosszul értelmezett buddhista filozófiai alapfogalomról részletesebben az irodalomjegyzékben feltüntetett, Porosz Tibor által jegyzett Szubjektív tudomány-objektív tudás c. könyvböl tájékozódhat (POROSZ 2018).
} 
ahol az ember a mindennapjait éli meg. Megtett utazásaink során gazdagszik a világ- és létismeretünk, a kommunikációs készletünk, és ha sok esetben tudattalanul is, a nyelvismeretünk. Ráadásul nem elhanyagolható módon szembesülünk a szociális státuszunkkal is, mely a már említett fennmaradási kényszerünkből és ösztönünkből ered.

Létünk házának berendezése és komfortossá tétele jó esetben egy életen át zajlik. Napjainkban akár tekinthetünk úgy önmagunkra, mint a világ pozitív újrafelfedezőire, akik az egyik órában még Rómában reggeliznek, az ebédet viszont már Prágában fogyasztják el, míg a vacsorájukat akár Budapesten, a saját lakásukban készítik el. Ez önmagában egy csodálatos lehetóség az ismeret elmélyítésre, ha kialakul az ehhez szükséges motiváció. Az utazási tevékenységben a rendelkezésünkre álló közlekedési eszközök és szolgáltatások a mi értelmezésünk szerint akadálymentesítő eszközök is.

Jaspers a filozófia alapfeladataként a kommunikációt nevezte meg, mely több irányban zajlik, így önmagunk és a külvilág szereplői között, valamint önmagunk belsố világával. A tudatos utazóvá válás tehát talán egy kommunikációs dimenzióváltáson keresztül képzelhetó el a legegyszerúbben. Itt LUHMANN (2010) nyomán bevezetjük az irritáció, az információ és az élmény hármas értelmezését, mely nem elsôsorban hierarchikus viszonyt feltételez, hanem azt igyekszik prezentálni, hogy a világunkat egyre súrúbben átszövő, információsnak nevezett háló elsősorban ingergeneráló szerepet tölt be. ${ }^{9}$ Ebból a tudatosság függvényében alakul ki a valós információ, majd ebból az értelmezési, kognitív és emocionális csomagból generálódhatnak az élmények. Abban, hogy miként alakul az inger információvá, majd esetleg élménnyé, a kommunikációs tevékenység központi szerepet játszik.

Azt állítjuk, hogy az egyre népszerúbbé váló utazási tevékenység, kelló és nem túl nagymértékú tudati erőfeszítéssel, arra is lehetőséget kínál, hogy a létezésünk megismerésébe és saját akadályozottságunk és segítségre szorultságunk világába is betekintsünk.

Ez az utazói tevékenység nevezhetô hermeneutikai, értelmezô felfedező túrának is, mely egyfajta valóság-visszacsatolást eredményezhet az utazás megvalósulása során. Hiszen, mint a statisztikák alátámasztják, az esetek többségében ma már az online felületek vizuálisan professzionális, ám emberileg igencsak rideg, világán keresztül vagyunk kénytelenek megszervezni a reményeink szerint

\footnotetext{
Jelen tanulmány keretei nem teszik lehetővé, hogy az említett hármas megközelítés filozófiai és rendszerelméleti részleteit is bemutassuk. Ezt a későbbiekben egy újabb tanulmányban részletesebben ismertetni fogjuk.
}

valós élményeket nyújtó, modernkori kalandozásainkat. Mindezek megvalósulása egy olyan belemerülés a valóság szövetébe, ami által valóban képet kaphatunk arról, hogy az elképzelt (leírt, fotókkal és videókkal alátámasztott) csodálatos helyszín mennyi olyan tulajdonságot hordoz, melyról még csak elképzelésünk sem volt. Sok esetben fel sem túnik, hogy az akadálymentesítés megvalósulása tulajdonképpen az általunk megvásárolt utazási történés összessége.

Jaspers életfilozófusként rendkívül fontosnak tartotta az ember kommunikációs adottságainak, képességeinek maximális megismerését és azok tökéletesítését (JASPERS 2008). De legalább ennyire fajsúlyosnak tekintette a Bergson-i és a Nágárdzsuna-i filozófiában is kiemelt helyet elfoglaló megismerési folyamatot, melynek lényege, hogy a létezés konkrét tapasztalati megismerése által folyamatosan alakítsuk ki és át azt a fogalmi keretrendszert, amivel leírjuk a körülöttünk lévó világot. Tehát az utazás és az utazó szimbiotikus módon cserél eszmét, többek között a létezésünk feltételeiről, így az ezerszínú emberi kultúra üresség természetún ${ }^{10}$ különbségeirôl és azok - a szükséges feltételek fennállása esetén - a legbelsőnket is elérő, így a személyiségünket formáló erejéról. Ez egy összetett, mégis könnyen megérthetô és megélhetô tudatmúködési folyamat. Ilyen értelemben beszél erről a XIV. Dalai Láma is, amikor azt fejtegeti, hogy a valóság önmagában hordozza a változást, jobban mondva a változás része és tükre is (GYATSO 2010).

\section{Az életfilozófia létértelmezési dimenziói egymástól kölcsönös függésben lévó szférákként}

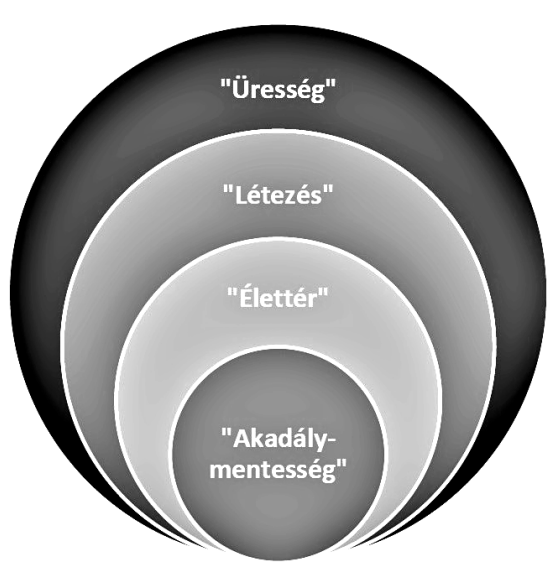

Forrás: saját szerkesztés RAFFAY-MARTON (2018) alapján

\footnotetext{
${ }^{10}$ Az ürességtan filozófiai iskolája szerint a dolgok csak egymást feltételezve létezhetnek. Ezért semmi sem áll meg önmagában, a dolgok üresség természetüek.
} 
Lektorált tanulmányok

A kicsi szép címú könyvet zöld és buddhista közgazdasági útmutatóként is szokták definiálni, amelyben SCHUMACHER (2014) mondanivalója összecseng a fent említett tudatos gondolkodási, életszemléleti és életvezetési módokkal. Továbbá gondolati rokonságot mutat a soron következő, a fenntarthatóság és az annak szerves részét képezó akadálymentesítési tevékenység összefüggéseibe bepillantást adó tanulmányfejezetünk üzeneteivel is. Az életbölcseleti létezésdimenziók egymáshoz illeszkedő szférákként történő értelmezése jól kapcsolódik a fenntartható fejlódés hasonló elven nyugvó megközelítéséhez (1. ábra).

\section{A fenntarthatóság és az akadálymentesség kapcsolódási területei a turizmusban}

Áttekintve a világgazdaság globális jellemzőit, biztosan állíthatjuk, hogy a fejlődés egyik kulcstényezője a turizmusipar növekedése. Igazolják ezt a jól ismert statisztikai adatok: a nemzetközi turistaérkezések száma 2017-ben 7\%-kal nőtt, ezzel a nemzetközi turisták száma meghaladta az 1,3 milliárd főt. A nemzetközi turizmus 1,6 billió dollár exportbevételt generált, amivel a világ GDP-jének $10 \%$-át adta, valamint a világon minden 10 munkahelyból egyet a turizmus ágazat biztosított (UNWTO 2018). Impozáns számok. Kiegészítve ezeket az adatokat a prognosztizált növekedési jellemzőkkel, az ágazat gazdasági értelemben vett jelentősége vitathatatlan.

A világgazdaságban játszott szerepe mellett azonban látni és értelmezni kell a turizmus további hatásait is. Ez a hatalmas volumenú ágazat rendkívüli hatást gyakorol a természeti környezet állapotára, ami rendkívül szembeötlő például azokban a desztinációkban, ahol a turizmus tömegjelenségként mutatkozik meg. A természeti környezetre gyakorolt káros hatásokat, a rombolás mértékét hosszú ideje nyomon követik a szakemberek az egyes desztinációkban. Az utazások számának növekedésével folyamatosan növekszik a közlekedés volumene a világon, és a közlekedési eszközök által kibocsátott káros anyagok egyre fokozódó terhet jelentenek az ökoszisztémára. A közlekedés egy igen számottevő részét tehát a növekvő turizmus generálja (PUCZKÓ-RÁTZ 2003), így az ágazat szerepe jelentős a környezeti terhelések növekedésében. A kedvező természeti adottságok viszont az egyik legfontosabb vonzeró csoportot képviselik a turizmusban, minek következtében kiemelkedó szerepük van az utazási célpontok kiválasztásakor. A természeti vonzerők növekvő utasforgalmat generálnak, ami növekvő terhelést jelent a természeti környezet szempontjából. A kialakuló tömegjelenségek egyre többször vetik fel a korlátok bevezetésének érveit, a felelős gondolkodás igényét a természeti értékek védelme érdekében.

Van azonban a turizmusnak még egy nehezen mérhetô hatása, amit vizsgálni kell, ez pedig a társadalomra gyakorolt hatás. Az utazás, a világ megismerése, az élményszerzés életünk részévé vált. Hozzásegít az életminőség javulásához, megteremti az egyének számára a változatosságot, kizökkent a hétköznapok munkamenetéből, és ezzel lehetôvé teszi a szellemi és a fizikai regenerálódást egyaránt. Sokak számára jelent ez vonzó alternatívát a szabadidő eltöltésére. Így tehát, ha minden szükséges feltétel teljesül (szabad rendelkezésú jövedelem, szabadidő, motiváció), útra kelünk. A közlekedési eszközök fejlődése és elterjedése, valamint az infokommunikációs lehetőségek bővülése szinte robbanásszerú változást idézett eló a turizmusban. Egyre több és több ember számára tette lehetôvé az utazást, miközben egyre több és több desztináció vált elérhetôvé, és a desztinációkról, a szolgáltatásokról, a közlekedési lehetőségekről egyre több információ vált hozzáférhetôvé, könnyen elérhetővé. Viszont az utazók és az utazások számának nagy ütemú növekedése az urbanizált terekben is tömegjelenségeket eredményezett.

A fentiekből adódóan kimagasló gazdasági eredmények, a természeti környezet fokozott és sokszor túlzott igénybevétele, valamint egyre több desztinációban a tömegesség és a tömegjelenségek jellemzik a turizmusiparágat. A sok pozitívum mellett megmutatkozó és már felismert negatív hatások kutatókat inspiráltak munkára. Ezeknek a kutatásoknak ez egyik fontos eredménye a fenntarthatóság fogalomkörének értelmezése a turizmus keretein belül.

A fenntartható turizmus a fenntartható fejlődés elvén alapszik, melynek lényege, hogy a kitúzött gazdasági növekedési célokat összefüggéseiben kell vizsgálni, azaz figyelemmel kell lenni a környezeti és a szociológiai hatásokra (BRUNDTLAND-JELENTÉS 1987). Az évek során a fenntartható fejlődés gazdasági-társadalmi-környezeti térben való elhelyezésének értelmezése is finomodott. Korábban a gazdasági és a társadalmi fejlődést, valamint a környezetvédelmet külön szférákként kezelték, amelyek közös halmazában jelenítették meg a fenntartható fejlódést (2. ábra). Mára azonban az a megközelítés vált elfogadottá, hogy a természeti környezet ad otthont a társadalomnak, melynek egyik tevékenysége a gazdaság fenntartható fejlesztése (RAFFAY-MARTON 2018). Az egyes szférák tehát inkább egymásba illeszkednek (3. ábra). 
2. ábra

A fenntartható fejlódés értelmezési aspektusai küiönálló szférák közös halmazaként

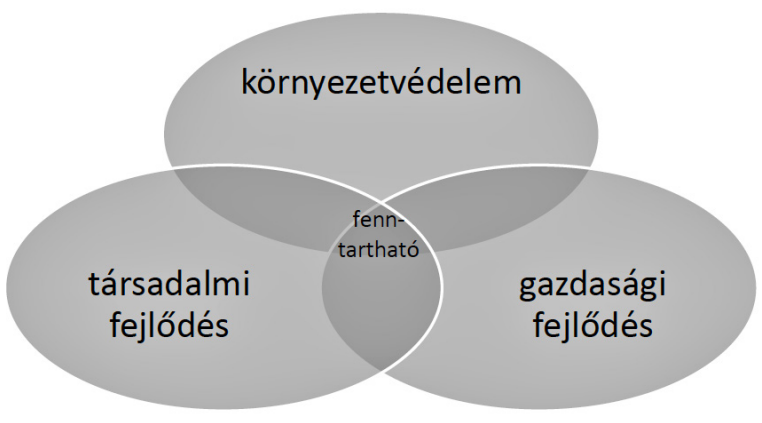

Forrás: saját szerkesztés FDSD (2019) és RAFFAY-MARTON (2018) alapján

3. ábra

A fenntartható fejlódés értelmezési aspektusai egymásba illeszkedó szférák részeként

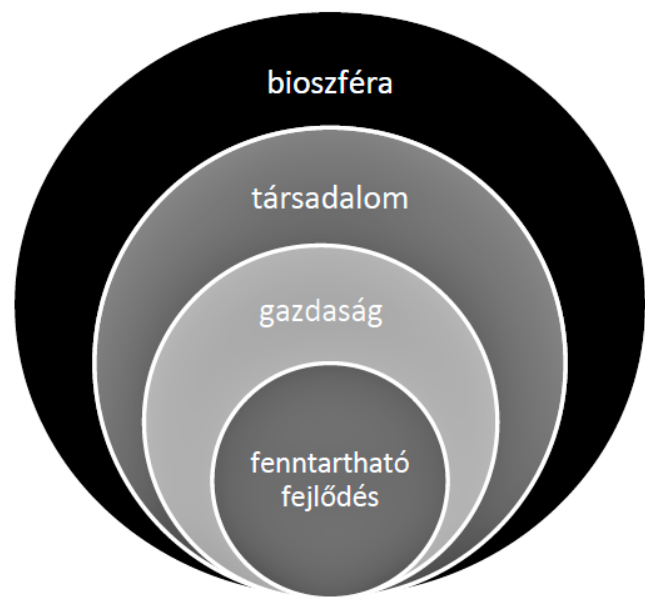

Forrás: saját szerkesztés RAFFAY-MARTON (2018) alapján

MICHALKÓ (2003) szerint a turizmus fenntarthatósága kettôs, a vonzerők megőrzését úgy kell megoldani, hogy közben biztosítjuk a turizmus vállalkozásainak sikerességét. A fenntarthatóság megvalósítása a turizmusban bonyolult feladat, amihez nem elegendő egyszerúen a nemzetközi szervezetek ajánlásait teljesíteni. A folyamatot tovább kell vinni, erősíteni kell a turizmus valamennyi szereplőjének tudatosságát és felelősségét is.

A fenntartható fejlôdés elve egyúttal azt is magába foglalja, hogy a rendszerösszefüggések következtében a célok kitúzésekor tiszteletben kell tartani bizonyos korlátokat (FLEISCHER 2014).
A turizmus fejlesztése és a megfelelő korlátok érvényesítése a fenntartható fejlődés érdekében, nehezen összeegyeztethető követelmények. Ezek megvalósítását segíti az a szemléletmód és magatartási forma, amit a felelősségteljes turizmus fogalomköre képvisel. A felelósségteljes turizmus az egyén és a társadalom felelősségvállalásán keresztül szemléli a fenntartható fejlődés lehetóségeit (HAPP 2014).

A turizmusfejlesztés fenntarthatóságához ugyanakkor szemléletváltásra van szükség minden szereplő részérôl, a turisták, a célterületek irányítói, valamint a szolgáltatók részéről egyaránt. A tevékenységekben minden esetben meg kell jelennie a tudatosságnak és a felelósségvállalásnak. A fogyasztói szokások megváltoztatásával, a települési önkormányzatok értékrendjének a fenntarthatóság elveihez való közelítésével, valamint a szolgáltatók józan önkorlátozásával még a tömegturizmus is felelősségteljesebbé tehető (MICHALKÓ 2003).

A kutatások révén tehát megfogalmazásra kerültek a legfontosabb alapelvek a turizmus fenntartható fejlódése érdekében, valamint kiemelésre kerültek olyan fogalmak, amelyek a feltételeit képezik ennek a fejlődésnek. Ezek a fogalmak a tudatosság és a felelősségvállalás.

A fenntartható fejlődés keretében azonban nem esett még szó egy lényeges alapelvről, a turizmus mindenkinek (Tourism for all) elvéról. A Turizmus Világszervezete (UNWTO) a Turizmus Globális Etikai Kódexének 7. cikkelyében fogalmazza meg a turizmushoz való jog elvét és benne az esélyegyenlőség biztosításának fontosságát.

A fogyatékossággal élók számára az esélyegyenlőséget az igénybe vehetô szolgáltatások akadálymentessége jelenti. Az akadálymentességet azonban mi, a tanulmány szerzói - ahogy azt a filozófiai megközelítésben már jeleztük - a szokásostól eltéró módon értelmezzük.

A hazai gyakorlatban a megkérdezettek az akadálymentesítés fogalma alatt általában a fizikai korlátok csökkentését, illetve megszüntetését értik - ahogy azt a filozófiai megközelítésben is érzékeltettük -, jellemzően építészeti tervezési és kivitelezési megoldásokkal. Ráadásul ezen belül is leginkább a mozgáskorlátozottak közlekedési feltételeinek megteremtésére gondolnak, pedig nem csak óket érintik, nem csak az ô mozgásukat korlátozzák a meglévő akadályok. Ezek az akadályok ugyanúgy korlátozzák például az idős emberek, a babakocsival közlekedő kisgyermekes anyukák vagy a családok, de még a kismamák mozgását is.

A hivatalos szervezetek természetesen pontosabban fogalmaznak: „Az akadálymentes turizmus a mindenki számára egyenló módon elérhető turizmust jelenti, amely fizikai, illetve értelmi ké- 
Lektorált tanulmányok

pességeiben akadályozottak számára is elérhetővé és élvezhetôvé teszi az ép társadalom utazóinak kínált turisztikai szolgáltatásokat." (MTÜ 2017). Az akadálymentes turizmust turisztikai termékként értelmezve, a célcsoportok meghatározásánál már megjelenítik azokat a társadalmi csoportokat, akik élethelyzetüknél vagy életkoruknál fogva érintettek az akadálymentes szolgáltatások kínálatának kialakításában. A hivatalos megfogalmazás, bár valóban törekszik formális leírást adni, mégis furcsa felhangot kap az ép társadalom kifejezés miatt. Jól láttatja azt az elkülönülést, elkülönítést, ami érzékenyen érinti a fogyatékossággal élőket, és egyben figyelmen kívül hagyja a további érintetteket. Véleményünk szerint többek között ezért is fontos lenne az akadálymentesség fogalmának általunk felvázolt kiterjesztése.

A Nemzeti Turizmusfejlesztési Stratégia 2030 már hozzáférhető turizmusról beszél, melynek megvalósítását a horizontális célok közé emeli. Cél a fizikai és az infokommunikációs akadálymentesítés (MTÜ 2018).

Akadálymentes turizmus az Európai Unióban (2012-2020)

4. ábra

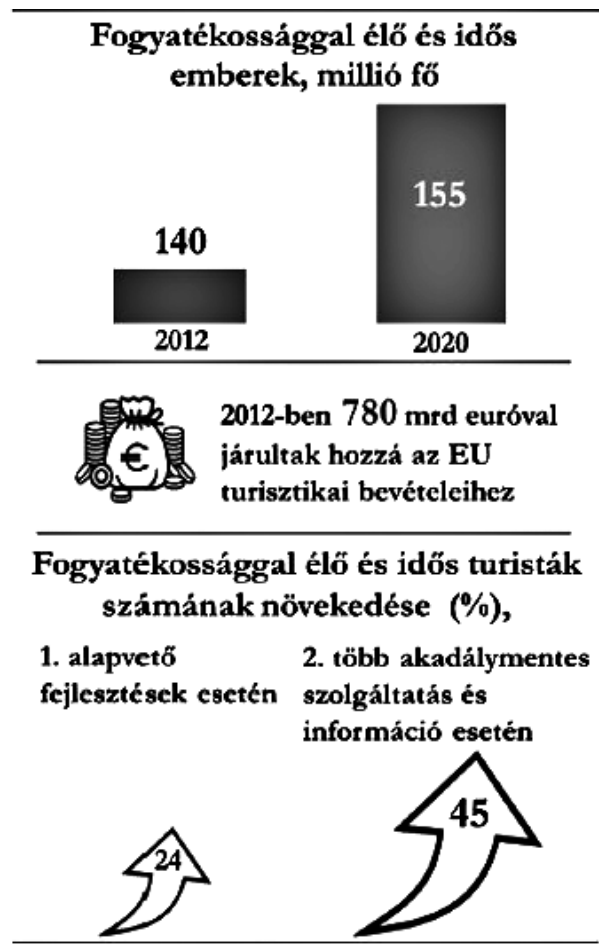

Forrás: EUROPEAN COMMISSION (2014) és ORSZÁGGYÜLÉS HIVATALA (2017)

Szükségét érezzük külön kiemelni azt a tényt, hogy az esélyegyenlőség és vele együtt az aka- dálymentesség biztosítása jelentős nagyságrendú népességet érint az Európai Unióban. Statisztikai adatok igazolják, hogy már 2012-ben is közel 140 millió lakos volt speciális hozzáférési igényú, ide számítva a fogyatékossággal élők mellett az idős korú (65+) lakosokat is. Az előrejelzések szerint 2020-ra az érintettek száma el fogja érni a 155 millió fốt (4. ábra). Ez a folyamatosan növekvő piac hatalmas gazdasági potenciállal rendelkezik, a számítások szerint az EU idegenforgalmi ágazata évente 142 milliárd eurót veszít azzal, hogy nem fordít elegendô figyelmet a speciális szükségletú utazók igényeinek kiszolgálására (EUROPEAN COMMISSION 2014).

Az utazásban és a turizmusban kulcsfontosságú az információhoz való hozzáférés. A vizsgálatok sajnos azt mutatják, hogy a fogyatékossággal élók nagyságrendileg hosszabb időt kell töltsenek az utazás megtervezésével, mint a nem fogyatékossággal élők, mivel nem áll rendelkezésükre megfelelő minóségú és mennyiségú információ a szolgáltatásokról. Az akadálymentességról való tájékoztatás egyértelmúen megnövelné az utasok számát, állítja az ENSZ egy tanulmánya (UN 2016).

Hozzáférhetó turizmus témakörben az Európai Bizottság Vállalkozáspolitikai és Ipari Fớigazgatósága ezidáig három tanulmányt publikált ${ }^{11}$. Ezek a tanulmányok elemzik az Unió hozzáférhetó turizmusának gazdasági oldalát, valamint vizsgálják a szegmens utazási szokásainak alakulását. 2012-ben az Európai Unió közel 50 millió fogyatékossággal élő lakosa 169,6 millió, egy naposnál hosszabb utazást bonyolított le, ami jelentôs gazdasági teljesítményként értékelhető (MEZŐ 2018). A kutatók szerint az akadálymentes turizmus megvalósulásának három fô akadálya van: a fizikai hozzáférést akadályozó tényezők, a szemléletbeli és a hozzáállással kapcsolatos problémák, valamint az információ hiánya (EICHHORN-BUCHALIS 2011).

Mindez azt mutatja, hogy a nemzetközi színtéren részletesebb elemzések és pontosabb ismeretek állnak rendelkezésre az akadálymentes turizmussal kapcsolatban, mint a hazai gyakorlatban. A filozófiai megközelítésben leírtakhoz hasonló gondolatmenettel azonban még nem találkoztunk. A fenntarthatóság olvasatában is úgy gondoljuk, elengedhetetlenül szükséges kiterjeszteni ezen alapvetố emberi tevékenység értelmezési horizontját. Meggyőződésünk, hogy a fenntartható fejlődés és az akadályok feltérképezése, majd elhárítása elválaszthatatlan és nem hierarchikus kapcsolatban, illetve viszonyban állnak egymással.

${ }^{11}$ Mapping skills and training needs to improve accessibility in tourism services (2014); Economic impact and travel patterns of accessible tourism in Europe (2014); Supply of accessible tourism services in Europe (2015). https://ec.europa.eu/info/index_en 
A fenntarthatóság és az akadálymentesítés olyan módon függ egymástól, mint a már többször említett szimbiotikus ember és a környezet. Akadálymentesítésre nemcsak a fizikai szükségletek, illetve a funkcionális fogyatékosság okán van szükség ${ }^{12}$, hanem - és ezt legalább annyira fontosnak tartjuk - az emberi tevékenység környezeti és társadalmi hatásainak sok esetben erodáló mivolta miatt is. Azaz mindenekelőtt fel kell ismernünk azt a paradoxont, mely a fenntarthatóság társadalmi környezetre gyakorolt hatásaiban rejlik. Az innovációk környezeti terhelést is jelentenek, és adott esetben a látszólagos fejlődés sok olyan életminőségbeli problémát generál, melyek klasszikus módon nem tekinthetôk akadályoknak, pedig véleményünk szerint azok. A tanulmány keretei a téma további kifejtésére nem adnak lehetôséget, de bízunk abban, hogy a filozófiai dimenzió és a fenntarthatóságról írt turizmusszakmai gondolatok összességében gondolatébresztôként funkcionálnak, és további tanulmányok születhetnek ebben a tárgykörben.

\section{6. Összegzés}

Az életfilozófia sajátos kutatási formája - a létezésünket az aktuális idô és történeti pillanatban értelmezni szándékozó - hermeneutika kereteinek e tanulmányban megkezdett kiterjesztési kísérlete, továbbá a vizsgálódásunk másik tengelyét adó fenntarthatósági elemzés módszertana együtt, úgy gondoljuk, kiállja a tudományosság királyvíz próbáját. Bízunk abban, hogy a fogyatékosság és az akadálymentesítés újszerú értelmezési kereteinek sikerül helyet találniuk a hétköznapi és a diszciplináris diskurzusokban egyaránt.

Napjainkra az utazás tudománya a társadalmi, a bölcseleti és a gazdasági problémák és lehetőségek feltérképezésének egyik multidiszciplináris konvergencia pontjává vált. Ennek jegyében íródott ez a sok esetben a konvencionális határokat áthágó tanulmány, melyben elsősorban nem válaszokat szándékoztunk megfogalmazni az aktuális (lét)történésekre, mint inkább új kérdésekkel kívántuk gazdagítani a létezés soha be nem teló útikönyvét.

Kutatásunk gondolatai mentén arra a következtetésre jutottunk, hogy a turizmustudományban a fenntarthatóság és az akadálymentesség összefüggő fogalmak. Az általunk bevezetett fogalmi kiterjesztés alapján az is elmondható, hogy a turizmus valamennyi dimenziójában az aka-

\footnotetext{
${ }^{12}$ Éppen ezért a hazai és a nemzetközi ide vonatkozó ajánlások és jogszabályok felemás képet mutatnak, hiszen javarészt a fizikai környezet elérhetőségének biztosítását hangsúlyozzák, úgy, mintha ezek önmagukban megálló entitások volnának egy modern kori társadalomban.
}

dálymentesség megvalósulása, legyen szó akár fizikai, akár kommunikációs, akár gondolkodásbeli, vagy más akadályokról, elengedhetetlen feltétele a fenntartható fejlődésnek. A megvalósításhoz pedig tudatos résztvevókre van szükség. Rá kell vennünk az utazókat, turistákat és a nekik szolgáltatásokat nyúitó vállalkozásokat arra, hogy az eddigieknél mélyebben gondolkodjanak és ilyen formán valódi felelősséget vállaljanak cselekedeteikért. Ószintén reméljük, tanulmányunkkal hozzá tudunk járulni ahhoz, hogy a tudatos, belegondoló, s ezáltal felelősségteljes utazói, utaztatói, befektetői, továbbá társadalomszervezési és irányítói magatartás elvei és gyakorlati tennivalói lábjegyzetból a fó fejezetek szintjére emelkedjenek a hazai turizmus, sőt, azon túl, az élet bármely területén.

A bemutatott - keleti és nyugati - bölcseleti, élmény, és tudásmorzsákból következóen bizakodunk abban, hogy a fogyatékosság és a kommunikáció tudománya, továbbá az életbölcseleti vizsgálódás is helyet találhat magának az utazás tudományának sokszínú ernyője alatt.

\section{Köszönetnyilvánítás}

Jelen publikáció az Európai Unió, Magyarország és az Európai Szociális Alap társfinanszírozása által biztosított forrásból az EFOP3.6.3-VEKOP-16-2017-00007 azonosítószámú „Tehetségból fiatal kutató - A kutatói életpályát támogató tevékenységek a felsőoktatásban" címú projekt keretében jött létre.

\section{Felhasznált irodalom}

ADLER, A. (1998): Életismeret. Kossuth Kiadó, Budapest.

BERGSON, H. (1987): Teremtó fejlődés. Akadémiai Kiadó, Budapest.

BRUNDTLAND-JELENTÉS (1988): Közös jövőnk. A Környezet és Fejlesztés Világbizottság jelentése. Mezőgazdasági Kiadó, Budapest.

EICHHORN, V. - BUCHALIS, D. (2011): Accessibility - A Key Objective for the Tourism Industry. In: Buchalis, D. - Darcy, S. (eds): Accessible Tourism: Concepts and Issues. Channel View Publications, Bristol. pp. 46-61.

EUROPEAN COMMISSION (2014): Accessible Tourism: "The new frontier of the sector". Enterprise and Industry Magazine. 20(2).pp. 18-19.

FARKAS J. (2019): Az akadálymentesítés primátusa a turisztikai termékfejlesztésben. In: Irimiás A. - Jászberényi M. - Michalkó G. (szerk.): A turisztikai termékek innovatív fejlesztése. Akadémiai Kiadó, Budapest. pp. 146-156. 
Lektorált tanulmányok

FLEISCHER T. (2014): A fenntarthatóság fogalmáról. In: Knoll I. - Lakatos P. (szerk.): Közszolgálat és fenntarthatóság. Nemzeti Közszolgálati Egyetem, Budapest. pp. 9-24.

GADAMER, H-G. (2003): Igazság és módszer. Osiris Kiadó, Budapest.

GEHLEN, A. (1976): Az ember. Gondolat Kiadó, Budapest.

GYATSO, T. (2010): Tibeti buddhizmus. Kulcs a középsố úthoz. Noran Libro Kiadó, Budapest.

HAPP É. (2014): Fenntartható turizmus és felelősségvállalás. Gazdaság és Társadalom. Journal of Economy \& Society. 6(1). pp. 90-101.

HEIDEGGER, M. (2019): Lét és idő. Osiris Kiadó és Szolgáltató Kft., Budapest.

JASPERS, K. (1996): Bevezetés a filozófiába. Európa Kiadó, Budapest.

JASPERS, K. (2008): Mi az ember? - Filozófiai gondolkodás mindenkinek. Media Nova Kft., Budapest.

KÁLMÁN Z. - KÖNCZEI G. (2002): A Taigetosztól az esélyegyenlőségig. Osiris Kiadó, Budapest.

KÖNCZEI GY. - HERNÁDI I. (2015): A fogyatékosságtudomány „térképei”. In: Hernádi I. - Könczei Gy. (szerk.): A felelet kérdései között. Fogyatékosságtudomány Magyarországon. Eötvös Loránd Tudományegyetem Bárczi Gusztáv Gyógypedagógiai Főiskolai Kar, Budapest.

KROPOTKIN, P. A. (1924): A kölcsönös segítség, mint természettörvény. Népszava Kiadó, Budapest.

LUHMANN, N. (2010): Ökológiai kommunikáció. Képes-e felkészülni a modern társadalom az ökológiai veszélyekre? Gondolat Kiadó, Budapest.

MEZÔ N. (2019): Az információk hozzáférhetôségének centrális jelentôsége az akadálymentes turizmusban. Szakdolgozat. BGE KVIK, Budapest.

MICHALKÓ G. (2003): A fenntartható fejlődés ökoturisztikai aspektusai Magyarországon. Turizmus Bulletin. 7(4). pp. 13-21.

MICHALKÓ G. (2010): Boldogító utazás. MTA Földrajztudományi Kutatóintézet, Budapest.

MICHALKÓ G. (2016): Turizmológia. Akadémiai Kiadó Zrt., Budapest.

MTÜ (2018): Nemzeti Turizmusfejlesztési Stratégia 2030. Magyar Turisztikai Ügynökség, Budapest.
POLÁNYI K. (2004): A nagy átalakulás. Korunk gazdasági és politikai gyökerei. Napvilág Kiadó, Budapest.

POROSZ T. (2018): Szubjektív tudomány - Objektív tudás. Tanulmányok a buddhizmusról. Gondolat Kiadó, Budapest.

PUCZKÓ L. - RÁTZ T. (2003): A turizmus hatásai. Aula Kiadó Kft., Budapest.

RAFFAY Z. - MARTON G. (2018): Fenntarthatóság a magyar turizmusban - hozzáállás vagy marketingfogás? In: Józsa L. - Korcsmáros E. - Seres Huszárik E. (szerk.): A hatékony marketing - EMOK 2018 Nemzetközi Tudományos Konferencia. Konferenciakötet. Selye János Egyetem, Komarno. pp. 667-677.

SCHUMACHER, E. F. (2014): A kicsi szép. Tanulmányok egy emberközpontú közgazdaságtanról. Katalizátor Könyvkiadó Kft., Budapest.

\section{Internetes források}

FDSD (FOUNDATION FOR DEMOCRACY AND SUSTAINABLE DEVELOPMENT) (2019): What is sustainable development? http://www.fdsd.org/the-challenge/whatis-sustainable-development/, Letöltve: 2019. július 20.

MTÜ (2017): Akadálymentes turizmus. https:// mtu.gov.hu/cikkek/akadalymentes-turizmus, Letöltve: 2019. július 20.

ORSZÁGGYÚLÉS HIVATALA (2017): Akadálymentes turizmus. https://www. parlament.hu/documents/10181/1202209/ Infojegyzet_2017_42_akadalymentes_ turizmus.pdf/c0f80467-094d-4e40-b5557f3c064f9106, Letöltve: 2019. július 20.

UN (2016): Promoting accessible tourism for all. https://www.un.org/development/desa/ disabilities/issues/promoting-accessibletourism-for-all.html, Letöltve: 2019. július 20.

UNWTO (2018): Tourism Highlights. 2018 Edition. $\quad$ https://www.e-unwto.org/doi/ pdf/10.18111/9789284419876, Letöltve: 2019. január 15. 